\title{
PERENCANAAN TUBUH BENDUNGANAIR LUAS KABUPATEN KAUR PROVINSI BENGKULU
}

\author{
Robet Firmansyah ${ }^{1)}$, Besperi ${ }^{2)}$ dan Muhammad Fauzi \\ ${ }^{1)}$ Alumni Program Studi Teknik Sipil Fakultas Teknik UNIB \\ Jl. W.R. Supratman, Kandang Limun,Bengkulu 38371 \\ ${ }^{2), 3)}$ Staf Pengajar Program Studi Teknik Sipil UNIB, Bengkulu \\ e-mail : besperimt@yahoo.com
}

\begin{abstract}
Abstrak
Tujuan penelitian ini adalah untukmerencanakan dimensi tubuh bendungan yang secara teknis layak untuk dibangun, serta aman terhadap stabilitas. Debit banjir rencana yang digunakan adalah sebesar 1.152 meter $^{3} / \mathrm{dt}$ dengan periode ulang 1000 tahun. Berdasarkan analisis yang telah dilakukan, didapatkan elevasi muka air banjir rencana adalah $+303,22$ meter, tinggi jagaan yang didapatkan sebesar 3,0 meter, elevasi puncak tubuh bendungan didapatkan + 306,22 meter, tinggi bendungan yang didapat dengan mengurangkan tinggi elevasi puncak tubuh bendungan dengan elevasi dasar bendungan adalah 56,16 meter, lebar mercu puncak bendungan sebesar 11,0 meter, kemiringan lereng urugan bagian hulu sebesar $1: 3$ dan untuk lereng urugan bagian hilir adalah $1: 2,25$. Menggunakan skema formasi garis depresi dengan drainase kaki dengan cara grafis, tidak terjadi rembesan yang keluar tubuh bendungan dan nilai kapasitas debit aliran filtrasi dari perhitungan didapatkanQ $=9,553 \times 10^{-5}$ meter $^{3} / \mathrm{dtk}<2 \%$ Qinflow rerata $=5,785$ meter $^{3} / \mathrm{dtk}$, bendungan aman terhadap aliran filtrasi. Stabilitas tubuh bendungan terhadap longsor dengan nilai faktor aman pada berbagai kondisi yaitu bendungan kosong dan terisi penuh baik dalam keadaan normal maupun terjadi gempa, untuk bendungan tipe urugan dengan menghitung beban tubuh bendungan, momen geser, tekanan air pori, serta beban gempa. Menggunakan metode irisan bidang luncur Fellenius, nilai yang didapatkan diatas angka aman $(1,2)$ maka bendungan yang direncanakan aman terhadap longsor.
\end{abstract}

Kata kunci : Bendungan, Perencanaan Tubuh Bendungan, Analisis,

MetodeFellenius

\begin{abstract}
The purpose of this study was to plan the dimensions of the dam body that is technically feasible to build, as well as secure the stability. Flood discharge plan used amounted to 1,152 meters cubic/ sec with a return period of 1000 years. Based on the analysis that has been done, get a plan of flood water level is $+303,22$ meters, surveillance obtained high of 3,0 meters, the body of the dam crest elevation gained $+306,22$ meters high dam that is obtained by subtracting the height elevation of the peak body dam with a base elevation of the dam is 56,16 meters, width of the dam crest beacon of 11.0 meters, rockfill the upstream slope of 1:3 and for rockfill downstream slope is 1: 2,.25. Using the scheme of depression line formation with drainage leg with a graphic way, do not occur out of the body dam seepage and flow filtration capacity value of the calculation, $Q=9,553 \times 10^{-5}$ meters cubic / sec, smallest than $2 \%$ Qinflow mean $=5,785$ mmeters cubic / sec, dam secure against flow filtration. The stability of the main dam of landslide with the value of safety factor in a variety of conditions, namely dams both empty and fully charged in a normal state or an earthquake, for rockfill dam by calculating the weight of the dam, sliding moment, pore water pressure and earthquake loads. Using the method of slices Fellenius glide plane, the value obtained above safe rate $(1,2)$, the planned dam safety to landslides
\end{abstract}

Keywords : Dam, Main Dam Design, Analysis, Fellenius Method 


\section{PENDAHULUAN}

Penyediaan air bersih merupakan salah satu indikator tingkat pelayanan pemerintah bagi masyarakat. Hal ini didasarkan bahwa air merupakan sumber daya yang dibutuhkan oleh semua mahkluk hidup atau bagi pemenuhan hajat hidup semua orang. Penyediaan air bersih sebagai salah satu sarana yang sangat diperlukan selama ini menjadi permasalahan yang banyak mengemuka terutama pada musim kemarau. Pada umumnya permasalahan yang timbul adalah ketersediaan air baku untuk air bersih yang sangat terbatas, berkurangnya produksi air bersih dalam kuantitas maupun kualitasnya.

Pasokan air baku untuk wilayah Kaur untuk saat ini dirasakan masih kurang, apalagi melihat proyeksi kebutuhan air baku untuk waktu yang akan dating (BWS Sumatera VII). Oleh karena itu upaya yang dilakukan oleh Balai Wilayah Sungai Sumatera VII adalah mengkaji cara meningkatkan keandalan pasokan air baku tersebut. Salah satu cara meningkatkan keandalan penyediaan air adalah dengan membuat tampungan. Untuk merealisasikan program tersebut, Kementerian Pekerjaan Umum melalui Balai wilayah Sumatera VII melakukan Kegiatan Perencanaan Pembangunan Bendungan Air Luas.

Desa Ulak Lebar Kabupaten Kaur Provinsi Bengkulu terletak sekitar $210 \mathrm{~km}$ di sebelah Utara Ibukota Propinsi Bengkulu. Desa ini mempunyai potensi lahan yang dapat dikembangkan terutama dalam sektor pertanian. Salah satu lahan potensial untuk pengembangan daerah irigasi yang diharapkan sebagai penghasil beras (lumbung padi) dan daerah penyangga untuk memenuhi kebutuhan masyarakat Kabupaten Kaur, Propinsi Bengkulu maupun Nasional.

Kekurangan pasokan air baku saat musim kemarau serta keberadaan listrik yang dirasa masih belum mencukupi di daerah yang berdampak langsung dengan sungai tersebut adalah salah satu alasan pemerintah melakukan pengembangan sumber daya air di lokasi tersebut. Lokasi perencanaan pembangunan bendungan ini merupakan jalan lintas penghubung provinsi Bengkulu dengan Sumatera Selatan, dengan adanya akses jalan tersebut secara langsung akan menjadikan Bendungan Air Luas sebagai wisata bendungan.

Bendungan yaitu bangunan melintang sungai yang berupa tanah, batu, beton atau pasangan batu yang dibangun selain untuk menahan dan menampung air, dapat juga dibangun untuk menampung limbah atau lumpur (Buana, 2010).

Tampungan air pada bendungan dialirkan untuk memenuhi beberapa tujuan yaitu bersifat eka guna (single purpose) misalnya keperluan irigasi saja, dan bersifat serba guna (multi purpose) misalnya untuk keperluan irigasi, pembangkit listrik, pengendali banjir, pengendali sedimen, dan lain sebagainya.

\section{Konstruksi Bendungan}

Bendungan direncanakan dengan menggunakan tipe urugan homogen. Perencanaan konstruksi bendungan harus dilakukan dengan analisis stabilitasnya sesuai kondisi dilapangan.

\section{Stabilitas Tubuh Bendungan Terhadap}

\section{Aliran Filtrasi.}

Analisis stabilitas bendungan dilakukan pada dua kondisi yaitu saat sungai normal dan saat sungai banjir. Pemeriksaan terhadap stabilitas bendungan harus dilakukan dengan teliti guna mendapatkan hasil yang lebih akurat. Garis depresi didapat dengan persamaan parabola bentuk dasar, untuk lebih jelasnya perhitungan garis depresi pada tubuh bendungan dapat dilihat pada Gambar 1 sumber : Rifai dan Kurniawan (2008)

Gambar 1. Garis depresi pada bendungan homogen 
Dihitung menggunakan persamaan berikut (Rifai dan Kurniawan, 2008) :

$$
\begin{aligned}
& \mathrm{d}=0,333 \mathrm{l}_{1}+\mathrm{l}_{2} \\
& \mathrm{y}_{0}=\sqrt{\mathrm{h}^{2}+\mathrm{d}^{2}}-\mathrm{d}
\end{aligned}
$$

Parabola bentuk dasar diperoleh dengan menggunakan persamaan berikut ini (Rifai dan Kurniawan, 2008) :

$$
y=\sqrt{2 y_{0} x+y_{0}{ }^{2}}
$$

Harga a untuk sudut kurang dari $30^{\circ}$ ditentukan dengan persamaan :

$$
\begin{aligned}
& \mathrm{a}=\frac{\mathrm{d}}{\cos \alpha}-\sqrt{\left(\frac{d}{\cos \alpha}\right)^{2} \cdot\left(\frac{\mathrm{h}}{\sin \alpha}\right)^{2}} \\
& \mathrm{a}+\Delta \mathrm{a}=\frac{\mathrm{y}_{0}}{1-\cos \alpha}
\end{aligned}
$$

di mana :

$\mathrm{h}=$ jarak vertikal antara titik A dan B (m)

$\mathrm{d}=$ jarak horisontal antara titik B2 dan A (m)

$l_{1}=$ jarak horisontal antara titik $\mathrm{B}$ dan $\mathrm{E}$ (m)

$1_{2}=$ jarak horisontal antara titik B dan A (m)

$\mathrm{A}=$ ujung tumit hilir embung

$\mathrm{B}=$ titik perpotongan antara permukaan air waduk dengan lereng hulu embung

$\mathrm{A}_{1}=$ titik perpotongan antara parabola bentuk besar garis depresi dengan garis

vertikal melalui titik B

$B_{2}=$ titik yang terletak sejauh $0,3 \quad l_{1}$ horisontal ke arah hulu dari titik B.

$\mathrm{x}=$ koordinat horizontal parabola.

$\mathrm{y} \quad=$ koordinat vertikal parabola.

$\mathrm{y}_{0}=$ Koordinat vertikal parabola saat $\mathrm{x}=$ 0.

$\mathrm{a}=$ jarak $\mathrm{A}$ ke C

$\Delta \mathrm{a}=\operatorname{jarak} \mathrm{C}_{0} \mathrm{ke}$

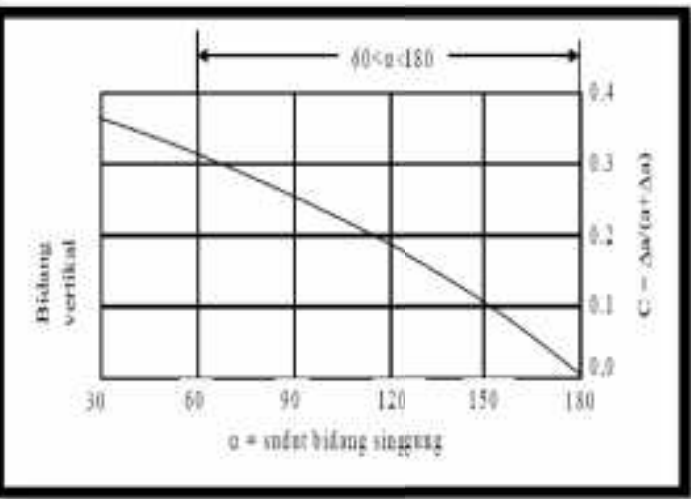

sumber : Christady, 1992

Gambar 2. Grafik nilai C

Debit rembesan yang lewat tubuh bendungan ditentukan dengan menggunakan persamaan berikut (Buana, 2010)

$$
Q_{f}=\frac{N_{f}}{N_{e}} k H ~ L
$$

di mana :

$\mathrm{Q}_{\mathrm{f}}=$ kapasitas aliran filtrasi

$\mathrm{N}_{\mathrm{f}}$ =angka pembagi dari garis trayektori aliran filtrasi

$\mathrm{N}_{\mathrm{e}}=$ angka pembagi dari garis equipotensial

$\mathrm{k} \quad=$ koefisien filtrasi

$\mathrm{H}=$ tinggi tekanan air total

$\mathrm{L}=$ panjang profil melintang tubuh bendungan

\section{Stabilitas Tubuh Bendungan Terhadap Longsor}

Adapun perhitungan faktor keamanan tubuh bendungan dari kemungkinan longsor didapatkan dengan persamaan berikut (Buana, 2010) :

$$
\begin{aligned}
& \mathrm{F}_{\mathrm{S}}=\frac{\sum\left\{\mathrm{C} \cdot 1+\left(\mathrm{N}-\mathrm{U}-\mathrm{N}_{e}\right) \tan \emptyset\right]}{\sum \mathrm{T}+\mathrm{T}_{\mathrm{e}}} \\
& \mathrm{F}_{\mathrm{S}}=\frac{\sum \mathrm{C} \cdot 1+\{\gamma \cdot \mathrm{A}(\cos \alpha-\mathrm{e} \cdot \sin \alpha) \cdot \mathrm{V}\} \tan \alpha}{\sum \gamma \cdot \mathrm{A}(\sin \alpha+\mathrm{e} \cdot \cos \alpha)}
\end{aligned}
$$

Dimana :

Fs = faktor keamanan

$\mathrm{N}$ = beban komponen vertikal yang timbul dari berat setiap irisan bidang luncur $(\gamma \cdot \mathrm{A} \cdot \cos \alpha)$

$\mathrm{T}=$ beban komponen tangensial yang timbul dari berat setiap irisan bidang $\operatorname{luncur}(\gamma . \mathrm{A} \cdot \sin \alpha)$ 
$\mathrm{U}=$ tekanan air pori yang bekerja pada setiap irisan bidang luncur

$\mathrm{Ne}=$ komponen vertikal beban seismis yang bekerja pada setiap irisan bidang luncur $(\mathrm{e} \cdot \gamma \cdot \mathrm{A} \cdot \sin \alpha)$

$\mathrm{Te}=$ komponen tangensial beban seismis yang bekerja pada setiap irisan bidang luncur $(\mathrm{e} \cdot \gamma \cdot \mathrm{A} \cdot \cos \alpha)$

$\varphi=$ sudut gesekan dalam bahan yang membentuk dasar setiap irisan bidang luncur

$\mathrm{C}$ = angka kohesi bahan yang membentuk dasar setiap irisan bidang luncur

$\mathrm{Z} \quad=$ lebar setiap irisan bidang luncur

e $\quad=$ intensitas seismis horisontal

$\gamma=$ berat isi dari setiap bahan pembentuk irisan bidang luncur

$\mathrm{A}=$ luas dari setiap bahan pembentuk irisan bidang luncur

$\alpha=$ sudut kemiringan rata-rata dasar setiap irisan bidang luncur

$\mathrm{V}=$ tekanan air pori

Gaya yang disebabkan oleh tekanan air pori atau gaya air ke atas saat tubuh bendungan jenuh air dihitung dengan persamaan berikut

$$
\mathrm{U}=\gamma_{\mathrm{w}} \cdot \mathrm{h} \cdot 1
$$

Dimana :

$$
\begin{aligned}
\mathrm{U} & =\text { gaya tekanan air pori }(\mathrm{t} / \mathrm{m}) \\
\gamma_{\mathrm{w}} & =\text { gama air } \\
\mathrm{h} & =\text { tinggi pias }(\mathrm{m}) \\
\mathrm{l} & =\text { lebar pias }(\mathrm{m})
\end{aligned}
$$

\section{METODELOGI PENELITIAN}

\section{Lokasi Penelitian}

Wilayah penelitian dibatasi pada kawasan hulu Air Luas Desa Ulak Lebar Kecamatan Muara Sahung Kabupaten Kaur.

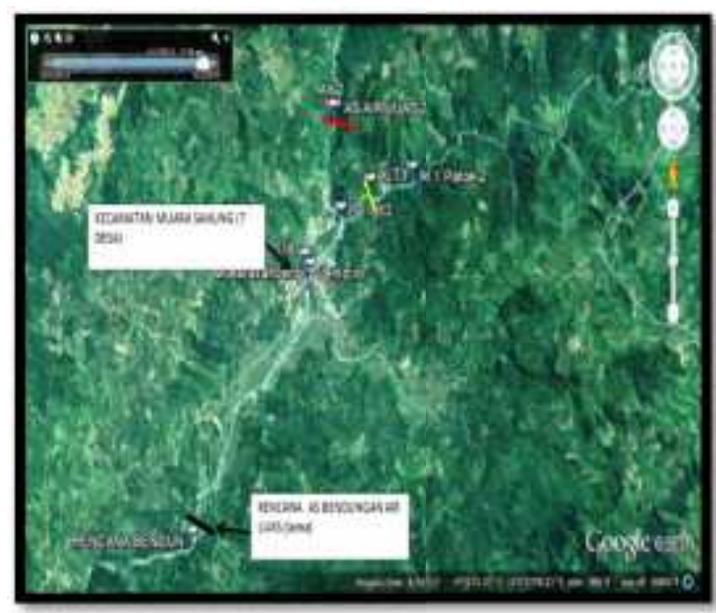

Gambar 3. Lokasi Penelitian (Google Earth, 2015)

\section{Metode Pengumpulan Data}

Adapun data yang dikumpulkan melalui dua jenis data yaitu:

\section{Data Primer}

Adapun data primer yang diambil pada penelitian ini adalah data dimensi sungai yang diukur langsung di lapangan menggunakan meteran, data kuat arus diukur menggunakan current meter atau menggunakan potongan styrofoam yang dihanyutkan pada jarak tertentu dihitung waktu tempuhnya, dan pengambilan data dokumentasi.

\section{Data sekunder}

Data-data sekunder yang digunakan dalam perencanaan ini diperoleh dari instansi adalah sebagai berikut:

1) Data Hidrologi, didapatkan dari Balai Wilayah Sungai Sumatera VII.

2) Data Topografi didapatkan dari Balai Wilayah Sungai Sumatera VII.

3) Data Geologi didapatkan dari Balai Wilayah Sungai Sumatera VII.

\section{Pelaksanaan Penelitian}

Pelaksanaan penelitian melewati beberapa tahapan adalah sebagai berikut: 


\section{Studi Pustaka}

Mempelajari literatur berupa kumpulan jurnal, buku, makalah, karya tulis dan skripsi yang berkaitan langsung dengan objek penelitian di lapangan.

Survei Pendahuluan

Survei pendahuluan merupakan survei awal pada skala kecil, dalam penelitian ini survei pendahuluan adalah penentuan lokasi penelitian.

\section{Survei Lapangan}

Pengamatan secara langsung dilapangan mengenai dimensi yang nantinya digunakan sebagai data dalam perencanaan bendungan.

\section{Pengolahan Data}

Perencanaan bendungan meliputi :

A. Perencanaan Konstruksi Bendungan

1. Tinggi jagaan.

2. Kemiringan lereng urugan.

3. Lebar mercu bendungan.

B. Analisis Stabilitas tubuh bendungan:

1. Stabilitas terhadap aliran filtrasi

a. Garis depresi tanpa drainase kaki

b. Garis depresi menggunakan drainase kaki c. Jaringan Trayektori aliran filtrasi

2. Stabilitas terhadap longsoran :

a. Kondisi baru selesai dibangun dan belum dialiri air

b. Kondisi bendungan terisi penuh

c. Kondisi terjadi gempa

\section{HASIL DAN PEMBAHASAN}

\section{Data Umum}

Data hidrologi dan topografi Air Luas yang didapatkan dari Balai Wilayah Sungai Sumatera VII adalah sebagai berikut :

a. Debit Banjir Rancangan

Data banjir rencana sebagai data dalam melakukan penelusuran banjir untuk mendapatkan elevasi muka air banjir pada rancangan bendungan Air Luas.

b. Elevasi As Bendungan

Data elevasi rencana as bendungan digunakan untuk menentukan elevasi dan ketinggian muka air normal bendungan. Data yang didapat adalah sebagai berikut Elevasi dasar sungai $=+250,06 \mathrm{~m}$ Elevasi As Bendungan $=+301,42 \mathrm{~m}$

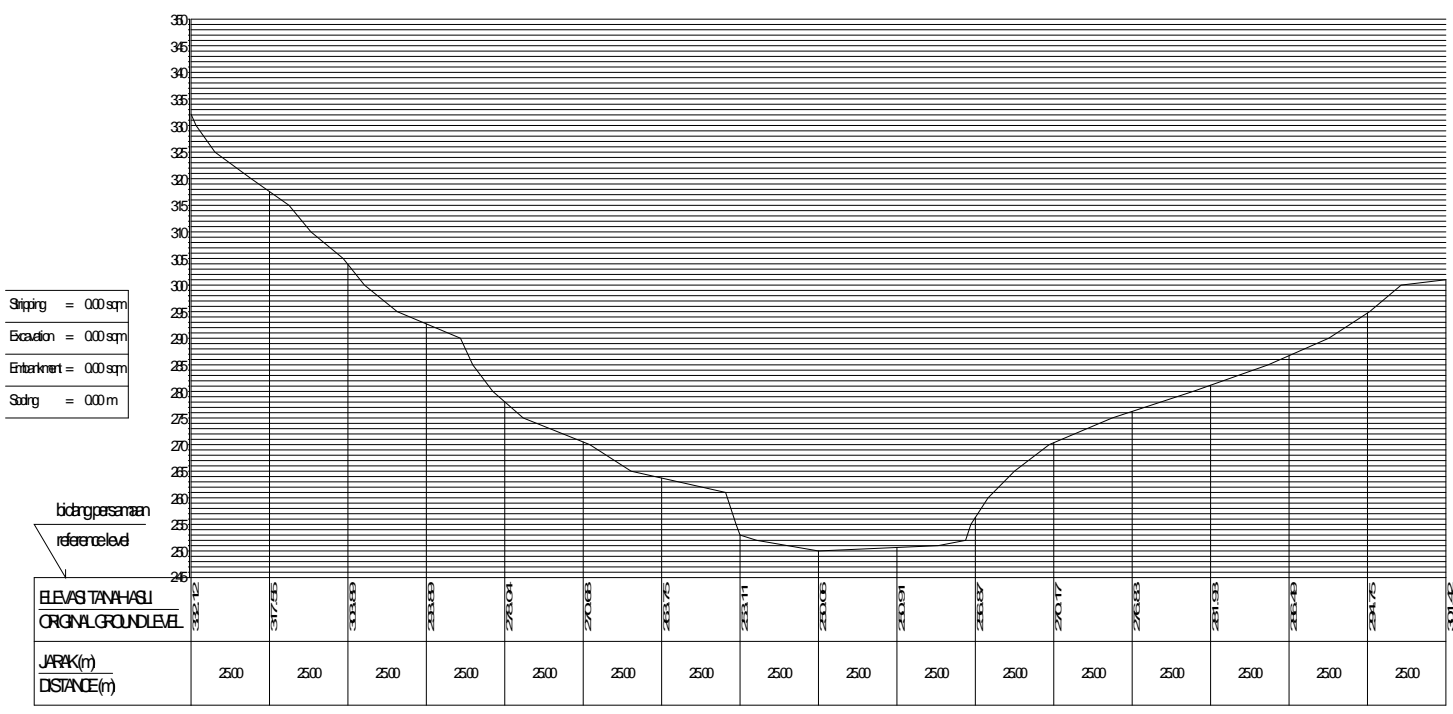

Gambar 4. Elevasi Rencana As Bendungan (BWSS VII, 2015) 
c. Hubungan Elevasi, Volume, dan Luas Bendungan

Data analisis hubungan antara elevasi, volume, dan luas genangan pada bendungan digunakan untuk menentukan elevasi muka air banjir berdasarkan nilai komulatif tampungan maksimum. Grafik hubungan antara elevasi, volume, dan luas genangan seperti terlihat pada Gambar 5.

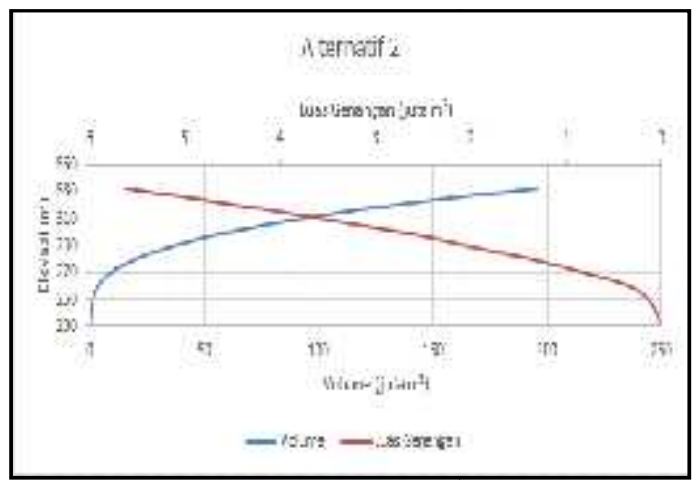

Gambar 5. Grafik hubungan antara elevasi, volume, dan luas genangan

Penelusuran Banjir (Flood Routing)

Penentuan Koefisien Debit Pelimpah

(Cd)

Koefisien debit limpasan dihitung dengan cara trial and eror dengan mencoba asumsi $\mathrm{Cd}=2$.

Digunakan pelimpah ambang lebar dengan volume sebagai berikut:

$\mathrm{Cd}=1,7-2,2$ dan biasanya 2-2,1 sudah memadai

$\mathrm{Cd}=2,0$ (asumsi)

$\mathrm{L}^{\prime}=52,26 \mathrm{~m}$ (lebar sungai)

$\mathrm{Q}=1151,98 \mathrm{~m}^{3} / \mathrm{dtk}$

$\mathrm{W}=51,36 \mathrm{~m}$

Saat $\mathrm{H}=\mathrm{Hd}$ dengan mercu berbentuk bulat didapatkan :

$\mathrm{Kp}=0,01$

$\mathrm{Ka}=0,12$

didapatkan nilai lebar efektif :

$$
\mathrm{L}=\mathrm{L}^{\prime}-2(\mathrm{n} . \mathrm{Kp}+\mathrm{Ka}) \mathrm{Hd}
$$

$\mathrm{L}=52,26-2(1.0,02+0,12) \mathrm{Hd}$

Maka didapatkan persamaan sebagai berikut :

$$
\begin{aligned}
& \mathrm{Q}=\mathrm{Cd} \mathrm{L} \mathrm{H}^{\frac{3}{2}} \\
& \mathrm{Q}=2(52,26-0,26 \mathrm{Hd}) \times \mathrm{Hd}^{\frac{3}{2}} \\
& \mathrm{Q}=(104,52-0,52 \mathrm{Hd}) \times \mathrm{Hd}^{\frac{3}{2}}
\end{aligned}
$$

Maka didapatkan nilai $\mathrm{Hd}=\mathrm{H}=5,037$ $\mathrm{m}$

Dari perhitungan diatas, nilai $\mathrm{Cd}$ dicek kebenarannya dengan menggunakan rumus Iwasaki :

$$
\begin{aligned}
& \mathrm{Cd}=2,200-0,0416 .(\mathrm{Hd} / \mathrm{W}) \\
& 2=2,2-0,0416(5,024 / 51,36) \\
& 2=2,1959 \text { (Asumsi Cd salah) }
\end{aligned}
$$

Selanjutnya perhitungan dilanjutkan dengan trial and error sampai didapatkan nilai $\mathrm{Cd}$ yang sama antara asumsi dengan hitungan, sehingga didapatkan nilai Cd seperti Tabel 1 .

Tabel 1. Perhitungan Nilai $\mathrm{Cd}$

\begin{tabular}{|c|c|c|}
\hline Cd asumsi & Hd (m) & Cd hitung \\
\hline 2,0000 & 5,0371 & 2,1959 \\
\hline 2,1000 & 4,8693 & 2,1960 \\
\hline 2,1900 & 4,7298 & 2,1962 \\
\hline 2,1961 & 4,7207 & 2,1961 \\
\hline
\end{tabular}

Sumber: Perhitungan

\section{Perhitungan Penelusuran Banjir}

Adapun data yang digunakan untuk melakukan penelusuran banjir adalah sebagai berikut :

a. Debit inflow untuk perencanaan bendungan diambil debit banjir dengan periode ulang 1000 tahun.

b. Grafik hubungan antara elevasi, volume, dan luas area permukaan waduk (Gambar 4.2).

c. Pelimpah ambang lebar dengan data sebagai berikut :

Elevasi mercu pelimpah $=+301,42$ $\mathrm{m}$ 
Perhitungan debit spillway dengan variasi tinggi muka air banjir yang melimpah di atas spillway disajikan dalam Tabel 2.

Dari Tabel 3. perhitungan penelusuran banjir, maka didapatkan bahwa nilai storage maksimum yaitu $63.993 .413 \mathrm{~m}^{3}$ pada elevasi $+303,22 \mathrm{~m}$. Data debit inflow dan outflow yang digunakan untuk penentuan nilai tinggi jagaan adalah data pada saat storage banjir mencapai negatif dan storage komulatif maksimum.

Tabel 2. Perhitungan debit outflow dengan berbagai nilai $\mathrm{H}$

\begin{tabular}{|c|c|c|c|c|}
\hline Cd & L & H & Qo & elv. Asumsi \\
\hline 2,1961 & 52,26 & 0,00 & 0 & 301,42 \\
\hline 2,1961 & 52,26 & 0,05 & 1,256216 & 301,47 \\
\hline 2,1961 & 52,26 & 0,10 & 3,553116 & 301,52 \\
\hline 2,1961 & 52,26 & 0,15 & 6,527491 & 301,57 \\
\hline 2,1961 & 52,26 & 0,20 & 10,04973 & 301,62 \\
\hline 2,1961 & 52,26 & 0,25 & 14,04493 & 301,67 \\
\hline 2,1961 & 52,26 & 0,30 & 18,46253 & 301,72 \\
\hline 2,1961 & 52,26 & 0,35 & 23,26545 & 301,77 \\
\hline 2,1961 & 52,26 & 0,40 & 28,42493 & 301,82 \\
\hline 2,1961 & 52,26 & 0,45 & 33,91784 & 301,87 \\
\hline 2,1961 & 52,26 & 0,50 & 39,72505 & 301,92 \\
\hline 2,1961 & 52,26 & 0,55 & 45,83038 & 301,97 \\
\hline 2,1961 & 52,26 & 0,60 & 52,21993 & 302,02 \\
\hline 2,1961 & 52,26 & 0,65 & 58,88158 & 302,07 \\
\hline 2,1961 & 52,26 & 0,70 & 65,80463 & 302,12 \\
\hline 2,1961 & 52,26 & 0,75 & 72,97957 & 302,17 \\
\hline 2,1961 & 52,26 & 0,80 & 80,39784 & 302,22 \\
\hline 2,1961 & 52,26 & 0,85 & 88,05171 & 302,27 \\
\hline
\end{tabular}


Tabel 3. Penelusuran Banjir (flood routing)

\begin{tabular}{|c|c|c|c|c|c|c|c|c|}
\hline $\begin{array}{c}Q \\
\text { inflow } \\
\left(\mathrm{m}^{3} / \mathrm{d}\right)\end{array}$ & $\begin{array}{c}Q i \\
\text { rata2 } \\
\left(\mathrm{m}^{3} / \mathrm{d}\right)\end{array}$ & $\begin{array}{c}\text { Vol Qir*t } \\
\left(\mathrm{m}^{3}\right)\end{array}$ & $\begin{array}{l}\text { asumsi } \\
\text { elevasi } \\
\text { (m) }\end{array}$ & $\begin{array}{c}\text { Q } \\
\text { outflow } \\
\text { (m) }\end{array}$ & $\begin{array}{c}\text { Qo } \\
\text { rata2 } \\
\left(\mathrm{m}^{3} / \mathrm{d}\right)\end{array}$ & $\begin{array}{l}\text { Vol } \\
\text { Qor*t } \\
\left(\mathrm{m}^{3}\right)\end{array}$ & $\begin{array}{c}\text { Storage } \\
\text { banjir } \\
\left(\mathrm{m}^{3}\right)\end{array}$ & $\begin{array}{c}\text { Storage } \\
\text { komulatif } \\
\left(\mathrm{m}^{3}\right)\end{array}$ \\
\hline \multirow[t]{2}{*}{5,42} & & & 301,42 & 0 & & & & 63827491 \\
\hline & 32,88 & 118353 & & & 3,264 & 11749 & 106604 & \\
\hline \multirow[t]{2}{*}{60,33} & & & 301,57 & 6,53 & & & & 63480779 \\
\hline & 138,4 & 498298 & & & 12,5 & 44982 & 453316 & \\
\hline \multirow[t]{2}{*}{216,50} & & & 301,97 & 18,46 & & & & 62210971 \\
\hline & 502,1 & 1807522 & & & 23,44 & 84397 & 1723124 & \\
\hline \multirow[t]{2}{*}{787,67} & & & 302,22 & 28,42 & & & & 60576380 \\
\hline & 969,8 & 3491375 & & & 37,13 & $1 \mathrm{E}+05$ & 3357715 & \\
\hline \multirow[t]{2}{*}{1151,98} & & & 302,42 & 45,83 & & & & 60413086 \\
\hline & 1034 & 3721952 & & & 55,82 & $2 \mathrm{E}+05$ & 3521009 & \\
\hline \multirow[t]{2}{*}{915,77} & & & 302,77 & 65,80 & & & & 61197861 \\
\hline & 840,9 & 3027363 & & & 80,87 & $3 E+05$ & 2736234 & \\
\hline \multirow[t]{2}{*}{766,10} & & & 303,02 & 95,93 & & & & 61871311 \\
\hline & 690,2 & 2484884 & & & 117,2 & $4 E+05$ & 2062784 & \\
\hline \multirow[t]{2}{*}{614,39} & & & 303,12 & 138,57 & & & & 62509497 \\
\hline & 558,1 & 2009039 & & & 162,3 & $6 \mathrm{E}+05$ & 1424598 & \\
\hline \multirow[t]{2}{*}{501,74} & & & 302,82 & 186,12 & & & & 62999681 \\
\hline & 455,8 & 1640988 & & & 196,3 & $7 E+05$ & 934414 & \\
\hline \multirow[t]{2}{*}{409,92} & & & 303,37 & 206,42 & & & & 63393277 \\
\hline & 372,5 & 1341024 & & & 222,3 & $8 E+05$ & 540818 & \\
\hline \multirow[t]{2}{*}{335,09} & & & 303,57 & 238,14 & & & & 63754614 \\
\hline & 304,6 & 1096553 & & & 254,7 & $9 \mathrm{E}+05$ & 179481 & \\
\hline \multirow[t]{2}{*}{274,10} & & & 303,22 & 271,3 & & & & 63993413 \\
\hline & 249,3 & 897307 & & & 265,7 & $1 E+06$ & -59318 & \\
\hline \multirow[t]{2}{*}{224,40} & & & 303,17 & 260,1 & & & & 63984618 \\
\hline & 204,1 & 734922 & & & 218,2 & $8 E+05$ & -50523 & \\
\hline \multirow[t]{2}{*}{183,89} & & & 302,77 & 176,2 & & & & 63948531 \\
\hline & 167,4 & 602576 & & & 171,4 & $6 \mathrm{E}+05$ & -14436 & \\
\hline \multirow[t]{2}{*}{150,87} & & & 302,72 & 166,5 & & & & 64021805 \\
\hline & 137,4 & 494715 & & & 161,8 & $6 \mathrm{E}+05$ & -87710 & \\
\hline \multirow[t]{2}{*}{123,97} & & & 302,67 & 157 & & & & 64043267 \\
\hline & 113 & 406807 & & & 143,3 & $5 E+05$ & -109172 & \\
\hline
\end{tabular}

Didapatkan nilai storage komulatif maksimum dari hasil pengurangan storage normal dengan storage banjir yaitu sebesar $63.993 .413 \mathrm{~m}^{3}$.

\section{Kemiringan Lereng Urugan}

Tubuh bendungan direncanakan dengan menggunakan lereng urugan homogen dikarenakan material di lokasi perencanaan bendungan tersebut berbutiran besar dan jumlah yang memadai untuk bahan urugan homogen. Didapakan kemiringan lereng urugan (vertikal : horizontal) hulu $1: 3$ dan hilir 1: 2,25.
Perencanaan Tinggi Tubuh Bendungan

Tinggi puncak bendungan merupakan hasil penjumlahan antara Didapatkan nilai storage komulatif maksimum dari hasil pengurangan storage normal dengan storage banjir yaitu sebesar $63.993 .413 \mathrm{~m}^{3}$.

\section{Kemiringan Lereng Urugan}

Tubuh bendungan direncanakan dengan menggunakan lereng urugan homogen dikarenakan material di lokasi perencanaan bendungan tersebut berbutiran besar dan jumlah yang memadai untuk bahan urugan homogen. Didapakan kemiringan lereng 
urugan (vertikal : horizontal) hulu $1: 3$ dan hilir 1: 2,25.

\section{Perencanaan Tinggi Tubuh Bendungan}

Tinggi puncak bendungan merupakan hasil penjumlahan antara tinggi bendungan dengan tinggi jagaan. Berdasarkan data topografi BWSS VII didapat elevasi muka air normal (MAN) adalah $+301,42 \mathrm{~m}$, elevasi muka air banjir (MAB) yang terjadi didapat adalah $+303,22 \mathrm{~m}$ sedangkan elevasi dasar kolam $+250,06 \mathrm{~m}$.

\section{Perencanaan Tinggi Jagaan}

Tinggi jagaaan perlu memperhitungkan aspek-aspek berikut ini :

a. Tinggi Kenaikan Permukaan Air Akibat Banjir Abnormal $(\Delta \mathrm{h})$

Tinggi kenaikan permukaan air akibat banjir abnormal dihitung menggunakan persamaan berikut ini:

$$
\Delta \mathrm{h}=\frac{2}{3} \frac{\alpha \mathrm{Q}_{0}}{\mathrm{Q}} \frac{\mathrm{h}}{1+\frac{\mathrm{A} \cdot \mathrm{h}}{\mathrm{Q} \cdot \mathrm{T}}}
$$

Dalam perhitungan digunakan data berikut:

$\alpha=0,2$ pelimpah direncanakan terbuka

$\mathrm{Q}_{0}=274,10 \mathrm{~m}^{3} / \mathrm{dt}$

$\mathrm{Q}=271,343 \mathrm{~m}^{3} / \mathrm{dt}$

$\mathrm{h}=4 \mathrm{~m}$ (rencana)

$\mathrm{T}=2 \mathrm{Jam}$

A $=1,07 \mathrm{~km}^{2}$ (data BWSS VII)

$\Delta \mathrm{h}=\frac{2}{3} \frac{0,2 \times 274,10}{271,343} \frac{4}{1+\frac{1,7 \times 4}{271,343 \times 2}}$

$\Delta \mathrm{h}=0,522 \mathrm{~m}$

b. Tinggi Ombak Akibat Angin $\left(\mathrm{h}_{\mathrm{w}}\right)$

Panjang lintasan ombak yang dipakai adalah $F_{\text {eff }}$ sebesar $425,37 \mathrm{~m}$ dari perhitungan . Sedangkan kecepatan angin (maksimal) di atas permukaan air embung diambil dari data di stasiun Bengkulu yaitu $20 \mathrm{~m} / \mathrm{dtk}$. Perhitungan tinggi ombak $\left(\mathrm{h}_{\mathrm{w}}\right)$ ini menggunakan grafik Metode SMB yang dikombinasikan dengan Metode Saville dalam Sasrodarsono (1989). Dengan kemiringan hulu 1:3 tinggi jangkauan ombak $\left(\mathrm{h}_{\mathrm{w}}\right)$ yang didapat adalah 0,21 $\mathrm{m}$. c. Tinggi Ombak Akibat Gempa $\left(\mathrm{h}_{\mathrm{e}}\right)$

Besarnya tinggi ombak yang diakibatkan oleh gempa (he) dihitung menggunakan persamaan berikut :

$h_{e}=\frac{e-\tau}{\pi} \sqrt{g \cdot h_{0}}$

Di mana :

e $\quad=$ Intensitas seismis horizontal $=0,3$

$\tau=$ Siklus seismis $=1$ detik

$\mathrm{h}_{0} \quad=$ Kedalaman air di dalam waduk (m)

= elv.M.A.B - elv.dasar kolam

$=303,22-250,06$

$=53,16 \mathrm{~m}$

$\mathrm{h}_{\mathrm{e}}=\frac{0,3,1}{3,14} \sqrt{9,81.53,16}$

$=2,2 \mathrm{~m}$

Tinggi permukaan ombak rata-rata adalah $\frac{\mathrm{h}_{e}}{2}$ $=1,1 \mathrm{~m}$

d. Kenaikan Muka Air Akibat Abnormal Operasional Pintu Bangunan $\left(h_{a}\right)$

Kenaikan permukaan air embung yang disebabkan oleh ketidaknormalan operasi pintu bangunan pada kontruksi bendungan (ha) diambil $=0,5 \mathrm{~m}$ (Sosrodarsono, 1977).

e. Angka Tambahan Tinggi Jagaan $\left(\mathrm{h}_{\mathrm{i}}\right)$

Angka tambahan tinggi jagaan yang didasarkan pada tipe embung (hi). Mengingat limpasan melalui mercu embung urugan sangat mungkin terjadi maka untuk embung tipe urugan ini angka tambahan tinggi jagaan (hi) ditentukan sebesar $(\mathrm{hi}=0.5 \mathrm{~m})$.

Tabel 4. Rekapitulasi Hasil Perhitungan Nilai $h$

\begin{tabular}{|c|c|}
\hline$\Delta \mathrm{h}$ & $0,522 \mathrm{~m}$ \\
\hline $\mathrm{h}_{\mathrm{w}}$ & $0,21 \mathrm{~m}$ \\
\hline$\frac{\mathrm{h}}{2}$ & $1,1 \mathrm{~m}$ \\
\hline $\mathrm{h}_{\mathrm{a}}$ & $0,5 \mathrm{~m}$ \\
\hline $\mathrm{h}_{\mathrm{i}}$ & $0,5 \mathrm{~m}$ \\
\hline
\end{tabular}

Berdasarkan perhitungan diatas, maka tinggi jagaan dapat ditentukan dengan persamaan sebagai berikut:

$\mathrm{H}_{\mathrm{f}} \geq \Delta h+\mathrm{h}_{\mathrm{w}}+\mathrm{h}_{\mathrm{a}}+\mathrm{h}_{\mathrm{i}}$

$\mathrm{H}_{\mathrm{f}}=0,522+0,21+0,5+0,5$

$=1,732 \mathrm{~m}$ 
Atau dengan persamaan :

$\mathrm{H}_{\mathrm{f}} \geq \Delta \mathrm{h}_{\mathrm{w}}+\frac{k_{e}}{2}+\mathrm{h}_{\mathrm{a}}+\mathrm{h}_{\mathrm{i}}$

$$
\mathrm{H}_{\mathrm{f}}=0,21+1,1+0,5+0,5
$$

$=2,31 \mathrm{~m}$

Dari perhitungan didapatkan tinggi jagaan 2,31 $\mathrm{m}$ atau kurang dari standar tinggi jagaan maka diambil tinggi jagaan 3 $\mathrm{m}$ atau harga minimal standar tinggi jagaan bendungan. Angka standard tinggi jagaan pada bendungan tipe urugan dalam Sosrodarsono (1977) adalah seperti pada Tabel 5.

Tabel 5. Angka Tinggi Jagaan Bendungan Urugan

\begin{tabular}{|l|c|}
\hline \multicolumn{1}{|c|}{$\begin{array}{c}\text { Tinggi } \\
\text { Bendungan }\end{array}$} & Tinggi Jagaan \\
\hline $\begin{array}{l}\text { Lebih rendah } \\
\text { dari } 50 \mathrm{~m}\end{array}$ & $\geq 2 \mathrm{~m}$ \\
\hline $\begin{array}{l}\text { Antara } 50- \\
100 \mathrm{~m}\end{array}$ & $\geq 3 \mathrm{~m}$ \\
\hline $\begin{array}{l}\text { Lebih tinggi } \\
\text { dari } 100 \mathrm{~m}\end{array}$ & $\geq 3,5 \mathrm{~m}$ \\
\hline \multicolumn{2}{|l|}{ Sumber : Sosrodarsono dan Takeda, 1989}
\end{tabular}

Digunakan tinggi jagaan $3 \mathrm{~m}$ selanjutnya elevasi puncan dan tinggi bendungan rencana dapat ditentukan seperti berikut ini: Elevasi puncak $=$ elevasi rencana + tinggi jagaan $=303,22+3=+306,22 \mathrm{~m}$

Tinggi Bendungan Rencana $=306,22-$ $250,06=56,16 \mathrm{~m}$

\section{Perencanaan Lebar Mercu Bendungan}

Lebar mercu bendungan sangat bergantung pada tinggi muka air banjir rencana ditambah tinggi jagaan yang dihitung dengan menggunakan persamaan seperti berikut ini :

$\mathrm{B}=3,6 \mathrm{H}^{\frac{1}{3}}-3$

$\mathrm{H}=$ tinggi bendungan $=56,16 \mathrm{~m}$

B $=3,6(56,16)^{1 / 3}-3,0$

B $=10,868 \mathrm{~m} \approx 11 \mathrm{~m}$

Diambil lebar mercu $11 \mathrm{~m}$ untuk memberikan keamanan terhadap longsoran lapisan kedap air dimana bendungan direncanakan tipe urugan.

\section{Perhitungan \\ Stabilitas \\ Tubuh \\ Bendungan}

\section{Stabilitas Lereng Bendungan Terhadap} Aliran Filtrasi

Stabilitas lereng bendungan terhadap rembesan dihitung dengan cara sebagai berikut :

a. Formasi garis depresi tubuh bendung kondisi tanpa menggunakan drainase kaki

Diketahui :

$\mathrm{h}=53,16 \mathrm{~m}$ (kondisi FSL)

$\mathrm{l}_{1}=154,27 \mathrm{~m}$

$1_{2}=140,57 \mathrm{~m}$

$\alpha=24^{\circ}$

dengan menggunakan persamaan, maka didapatkan nilai :

$$
\begin{aligned}
\mathrm{d} & =0,333 \mathrm{l}_{1}+\mathrm{l}_{2} \\
& =(0,333 \times 154,27)+140,57 \\
& =191,942 \mathrm{~m}
\end{aligned}
$$

Dari data diatas maka didapatkan nilai $\mathrm{y}_{0}$ dengan menggunakan persamaan :

$$
\begin{aligned}
\mathrm{y}_{0} & =\sqrt{\mathrm{h}^{2}+\mathrm{d}^{2}}-\mathrm{d} \\
& =\left(\sqrt{53,16^{2}+191,942^{2}}\right)-191,942
\end{aligned}
$$

$=7,226 \mathrm{~m}$

Parabola bentuk dasar garis depresi tubuh bendungan diperoleh dengan menggunakan persamaan berikut :

$$
\begin{aligned}
\mathrm{y} & =\sqrt{2 \mathrm{y}_{0} \mathrm{x}+\mathrm{y}_{0}{ }^{2}} \\
\mathrm{y} & =\sqrt{2 \cdot 7,226 \mathrm{x}+7,226^{2}}
\end{aligned}
$$

Dari persamaan y diatas didapatkan koordinat parabola garis depresi seperti terlihat pada Tabel 5 . 
Tabel 5. Koordinat Parabola tanpa drainase kaki

\begin{tabular}{|c|c|c|c|c|c|c|}
\hline $\mathbf{x}$ & $-3,613$ & 0 & 20 & 40 & 60 & 80 \\
\hline $\mathbf{y}$ & 0 & 7,226 & 18,472 & 25,105 & 30,320 & 34,761 \\
\hline $\mathbf{x}$ & 100 & 120 & 140 & 160 & 180 & 191,94191 \\
\hline $\mathbf{y}$ & 38,695 & 42,265 & 45,556 & 48,625 & 51,511 & 53,160 \\
\hline
\end{tabular}

Sumber : Perhitungan

Untuk $\alpha$ kurang dari $30^{\circ}$, maka harga a dengan persamaan adalah :

$\mathrm{a}=\frac{\mathrm{d}}{\cos \alpha}-\sqrt{\left(\frac{\mathrm{d}}{\cos \alpha}\right)^{2}-\left(\frac{\mathrm{h}}{\sin \alpha}\right)^{2}}$

Maka didapatkan nilai $\mathrm{a}+\Delta \mathrm{a}$ dengan persmaan :

$\mathrm{a}+\Delta \mathrm{a}=\frac{\mathrm{y}_{0}}{1-\cos \alpha}$

$\mathrm{a}+\Delta \mathrm{a}=\frac{7,226}{1-\cos 24^{\circ}}$

$\mathrm{a}+\Delta \mathrm{a}=83,571 \mathrm{~m}$

$\mathrm{a}=\frac{191,942}{\cos 24}-\sqrt{\left(\frac{191,942}{\cos 24}\right)^{2}-\left(\frac{53,16}{\sin 24}\right)^{2}}$

a $=45,608 \mathrm{~m}$

sehingga didapatkan nilai sebagai berikut :

$\Delta \mathrm{a}=83,571-45,608$

$\Delta \mathrm{a}=37,962 \mathrm{~m}$

Dari hasil perhitungan didapatkan garis depresi aliran yang keluar melalui lereng hilir bendungan sehingga bendungan tidak aman, dapat dilihat pada Gambar 4.3 Untuk mengatasi hal tersebut diperlukan penggunaan drainase kaki pada bendungan agar bendungan aman.

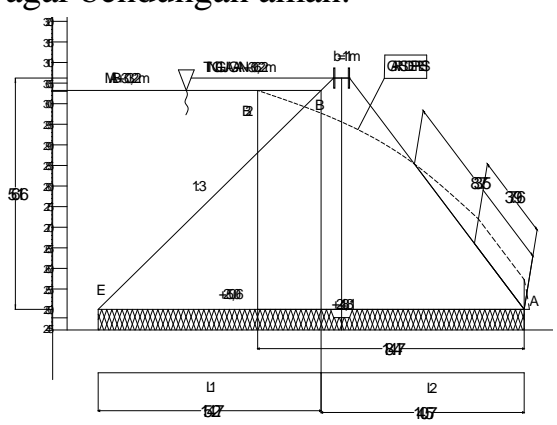

Gambar 6. Garis Depresi Tubuh Bendungan Tanpa Drainase Kaki

b. Formasi garis depresi tubuh bendung kondisi dengan menggunakan drainase kaki

Diketahui :

$\mathrm{h}=54,16 \mathrm{~m}$ (kondisi FSL)

$l_{1}=154,27 \mathrm{~m}$

Jurnal Inersia April 2017 Vol.9 No.1

Email: Inersia@unib.ac.id
$1_{2}=110,57 \mathrm{~m}$

$\alpha=135^{\circ}$

dengan menggunakan persamaan, maka didapatkan nilai :

$\mathrm{d}=0,333 \mathrm{l}_{1}+\mathrm{l}_{2}$

$=(0,333 \times 154,27)+110,57$

$=161,942 \mathrm{~m}$

Dari persamaan maka didapatkan :

$$
\begin{aligned}
\mathrm{y}_{0} & =\sqrt{\mathrm{h}^{2}+\mathrm{d}^{2}}-\mathrm{d} \\
& =\sqrt{54,16^{2}+161,942^{2}}-161,942 \\
& =8,502 \mathrm{~m}
\end{aligned}
$$

Parabola bentuk dasar diperoleh dengan menggunakan persamaan 2.13 :

$y=\sqrt{2.8,502 x+8,502^{2}}$ 
Tabel 6. Koordinat Parabola Dengan Drainase Kaki

\begin{tabular}{|c|c|c|c|c|c|c|}
\hline $\mathbf{X}$ & $-4,251$ & 0 & 15 & 20 & 60 & 80 \\
\hline $\mathbf{Y}$ & 0 & 8,502 & 18,093 & 20,307 & 33,054 & 37,850 \\
\hline $\mathbf{X}$ & 100 & 120 & 140 & 150 & 160 & 161,94191 \\
\hline $\mathbf{Y}$ & 42,104 & 45,965 & 49,527 & 51,214 & 52,849 & 53,160 \\
\hline
\end{tabular}

Sumber : Perhitungan

Untuk $\alpha=135^{\circ}$, maka harga a didapat sebagai berikut :

Dari Gambar 2.6 didapatkan nilai

$\mathrm{C}=\frac{\Delta a}{a+\Delta a}=0,15$

$\mathrm{a}+\Delta \mathrm{a}=\frac{\mathrm{y}_{0}}{1-\cos \alpha}$

$\mathrm{a}+\Delta \mathrm{a}=\frac{8,502}{1+0,707}$

$\mathrm{a}+\Delta \mathrm{a}=4,981 \mathrm{~m}$

$0,15=\frac{\Delta a}{a+\Delta a}$

$\Delta \mathrm{a} \quad=0,15 \times 4,981$

$\Delta \mathrm{a} \quad=0,747 \mathrm{~m}$

sehingga didapatkan nilai a sebagai berikut:

a $\quad=4,981-0,747$

a $\quad=4,234 \mathrm{~m}$

untuk lebih jelasnya dapat dilihat pada Gambar 7.

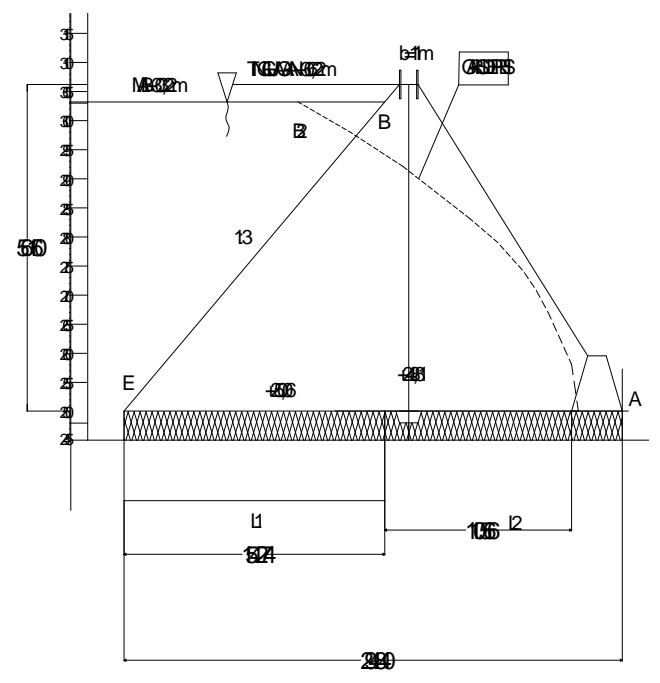

Sumber : Perencanaan

Gambar 7. Garis Depresi Tubuh Bendungan Dengan Drainase Kaki

c. Jaringan Trayektori aliran filtrasi (seepage flow-net)

Kapasitas aliran filtrasi asumsi $\mathrm{Kh}=\mathrm{Kv}$

Dihitung dengan menggunakan persamaan:

Data yang ada di dapat :

Jurnal Inersia April 2017 Vol.9 No.1

Email: Inersia@unib.ac.id
$\mathrm{Nf}=3$ (asumsi)

$\mathrm{Ne}=26$ (asumsi)

$\mathrm{k}=5 \times 10^{-6} \mathrm{~cm} / \mathrm{dtk}=5 \times 10^{-8} \mathrm{~m} / \mathrm{dtk}$ (asumsi)

$\mathrm{H}=56,16 \mathrm{~m}$

$\mathrm{L} \quad=294,84 \mathrm{~m}$

Maka debit aliran filtrasi adalah sebagai berikut :

$$
\begin{aligned}
\mathrm{Q}_{\mathrm{f}} & =\frac{\mathrm{N}_{\mathrm{f}}}{\mathrm{N}_{\mathrm{e}}} \mathrm{kH} \mathrm{L} \\
& =\frac{3}{26} 5 \times 10^{-8} \times 56,16 \times 294,84 \\
& =9,553 \times 10^{-5} \mathrm{~m} 3 / \mathrm{dtk} \text { (Syarat Q lebih }
\end{aligned}
$$

kecil dari 2\% Qinflow rata-rata waduk)

Maka $Q=9,553 \times 10^{-5} \mathrm{~m} 3 / \mathrm{dtk}<5,785$ m3/dtk (aman)

Stabilitas Lereng Bendungan Terhadap Longsor Metode Fellenius

Adapun data teknis perencanaan tubuh bendungan adalah sebagai berikut:

Tinggi Puncak Bendungan $=56,16 \mathrm{~m}$

Elevasi Air Waduk

$=+303,16 \mathrm{~m}$

Lebar Mercu Embung $\quad=11 \mathrm{~m}$

Kemiringan Hulu $\quad=1: 3$

Kemiringan Hilir $\quad=1: 2,25$ 
Tabel 7. Kondisi Perencanaan Teknis Material Urugan

\begin{tabular}{|c|c|c|c|c|c|c|c|c|}
\hline \multirow{2}{*}{$\begin{array}{c}\text { Zona Tubuh } \\
\text { Bendungan }\end{array}$} & \multicolumn{2}{|c|}{ Kuat Geser } & \multicolumn{5}{|c|}{ abunan dalam beberapa kondisi } & \multirow{2}{*}{$\begin{array}{c}\text { Intensitas } \\
\text { beban siesmis }\end{array}$} \\
\hline & $\begin{array}{c}\mathrm{C} \\
\left(\mathrm{t} / \mathrm{m}^{3}\right)\end{array}$ & $\begin{array}{l}\frac{1 T}{10} \\
\frac{\pi}{6}\end{array}$ & 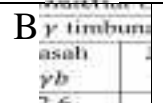 & 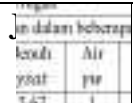 & 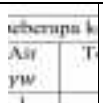 & Te & 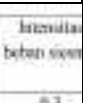 & \\
\hline $\begin{array}{c}\text { Zona kedap } \\
\text { air }\end{array}$ & 29,4 & 20 & 2,6 & 2,67 & 1 & 1,67 & & 0,3 \\
\hline
\end{tabular}

Sumber : BWSS VII

Analisis Stabilitas lereng menggunakan metode irisan bidang luncur bundar Fellenius. Kestabilan terhadap longsor dihitung dengan mengguthakan Persamaan berikut :

$\mathrm{F}_{\mathrm{s}}=\frac{\sum\left\{\mathrm{C} \cdot 1+\left(\mathrm{N}-\mathrm{U}-\mathrm{N}_{\mathrm{e}}\right) \tan \emptyset\right]}{\sum \mathrm{T}+\mathrm{T}_{\mathrm{e}}}$

Adapun contoh langkah pengerjaannya adalah sbagai berikut :

a. Bendungan Baru Dibangun Belum Dialiri Air Kondisi Normal Hulu

1. Menentukan jari-jari bidang longsor (r) sampai tepi lingkaran bersinggungan dengan dasar pondasi menggunakan bantuan aplikasi autocad. Pada penggambaran didapatkan nilai jarijari $\mathrm{r}=181,337 \mathrm{~m}$.

2. Membagi bidang longsoran menjadi beberapa bagian, kemudian masingmasing pias dihitung luas (A) dan gaya beratnya (W). Untuk pias 1, didapatkan :
A $=159,22 \mathrm{~m}^{2}$
$\mathrm{W}=\mathrm{A} \cdot \gamma \mathrm{b}$
$\mathrm{W}=159,22 \times 2,6$
$\mathrm{W}=413,97 \mathrm{t} / \mathrm{m}$

3. Menentukan sudut yang dibentuk oleh jari-jari bidang longsor $(\alpha)$ dengan arah gaya berat masing-masing pias. Untuk pias 1 bidang longsor didapatkan nilai $\alpha=-5,345^{\circ}$

4. Menghitung momen yang menyebabkan geser pada bidang longsor tubuh bendungan. Untuk pias 1 didapatkan nilai sebagai berikut :

$$
\begin{aligned}
\mathrm{T} & =\mathrm{W} \cdot \sin \alpha \\
\mathrm{T} & =413,97 \mathrm{x} \sin -5,345^{\circ} \\
\mathrm{T} & =-38,60 \mathrm{t} / \mathrm{m}
\end{aligned}
$$

5. Menghitung momen yang menahan bidang longsor pada bendungan. Untuk pias 1 didapatkan nilai sebagai berikut

$\mathrm{N}=\mathrm{W} \cdot \cos \alpha$

$\mathrm{N}=413,97 \cdot \cos -5,345^{\circ}$

$\mathrm{N}=412,17 \mathrm{t} / \mathrm{m}$

6. Selanjutnya mencari nilai faktor keamanan Fs atau Sf. Dengan menggunakan persamaan 2.18 maka didapatkan nilai Fs sebagai berikut :

Fs $=\frac{\sum[\mathrm{C} \cdot 1+(\mathrm{N} \cdot \mathrm{U}-\mathrm{Ne}) \tan \emptyset]}{\sum(\mathrm{T}+\mathrm{Te})} \geq 1,2$

Fs $=3,25 \geq 1,2$ (aman)

Maka tubuh bendungan bagian hulu belum dialiri air kondisi normal aman terhadap gaya longsoran.

7. Prosedur perhitungan di atas diulang sampai semua pias yang membentuk bidang longsor dianalisis tanpa terkecuali.

b. Bagian Hulu Bendungan Terisi Air Penuh Pada Keadaan Gempa

1. Prosedur perhitungan seperti sebelumnya, namun nilai $\mathrm{W}$ yang dipakai adalah jumlah dari $\mathrm{W}$ basah dan W kering karena pada saat terisi air ada bagian dari pias yang terkena air dan ada juga yang tidak. Untuk pias 8 didapatkan nilai sebagai berikut :

$$
\begin{aligned}
& \mathrm{W}_{\text {tot }}=\mathrm{A}_{\mathrm{w}} \cdot \gamma_{\mathrm{sat}}+\mathrm{Ad} \cdot \gamma_{\mathrm{b}} \\
& \mathrm{W}_{\text {tot }}=47,21 \cdot 2,67+93,62 \cdot 2,6 \\
& \mathrm{~W}_{\text {tot }}=246,7 \mathrm{t} / \mathrm{m}
\end{aligned}
$$

2. Gaya yang disebabkan oleh tekanan air pori atau gaya air ke atas saat tubuh bendungan jenuh air. Dari perhitungan didapatkan nilai $U$ menggunakan persamaan 2.20 sebagai berikut :

$$
\mathrm{U}=\gamma_{\mathrm{w}} \cdot \mathrm{h} .1
$$




$$
\begin{aligned}
\mathrm{U} & =1.0 .27,62 \\
\mathrm{U} & =0 \mathrm{t} / \mathrm{m}
\end{aligned}
$$

3. Komponen vertikal dan tangensial beban siesmis yang masing-masing dapat ditentukan dengan persamaan berikut ini :

$$
\begin{aligned}
\mathrm{Ne} & =\mathrm{k} \cdot \mathrm{W} \cdot \sin \alpha \\
& =0,3 \cdot 246,7 \cdot 0,668 \\
& =49,47 \mathrm{t} / \mathrm{m} \\
\mathrm{Te} & =\mathrm{k} \cdot \mathrm{W} \cdot \cos \alpha \\
& =0,3 \cdot 246,7 \cdot 0,744
\end{aligned}
$$

$$
\begin{aligned}
\mathrm{Fs} & =\frac{\sum 5,05 \mathrm{t} / \mathrm{m}}{\sum(T+T e)} \\
& =\frac{5742,94+331,17}{3941,42} \\
& =1,54 \geq 1,2 \text { (aman) }
\end{aligned}
$$

Dari semua perhitungan stabilitas lereng bendungan terhadap longsor didapatkan bahwa tubuh bendungan aman terhadap longsor.

Tabel 8. Rekapitulasi stabilitas tubuh bendungan terhadap longsor

\begin{tabular}{|c|c|c|c|c|c|c|c|c|}
\hline Zona & \multicolumn{4}{|c|}{ Hulu Bendungan } & \multicolumn{4}{c|}{ Hilir Bendungan } \\
\hline Kondisi & Normal & Ket. & Gempa & Ket. & Normal & Ket. & Gempa & Ket \\
\hline Kosong & 3,25 & aman & 1,67 & aman & 3,14 & Aman & 1,79 & aman \\
\hline MAB & 3,01 & aman & 1,54 & aman & 2,87 & aman & 1,72 & aman \\
\hline
\end{tabular}

Sumber: Perhitungan

\section{KESIMPULAN}

\section{Kesimpulan}

1. Dengan cara grafis, pada kondisi tanpa menggunakan drainase kaki terjadi aliran keluar dari tubuh bendungan, maka bendungan dinyatakan belum aman. Untuk itu perlu direncanakan drainase kaki, setelah dilakukan perhitungan dengan drainase kaki aliran diluar tubuh bendungan tidak terjadi, maka bendungan aman. Kapasitas debit aliran filtrasi $\mathrm{Q}=$ $9,553 \times 10^{-5} \mathrm{~m}^{3} / \mathrm{dtk}$ lebih kecil dari $2 \%$ Qinflow rerata $=5,785 \mathrm{~m}^{3} / \mathrm{dtk}$, bendungan aman terhadap aliran filtrasi.

2. Nilai stabilitas lereng terhadap longsoran pada tubuh bendungan bagian hulu kondisi normal belum terisi air, dan bagian hulu kondisi normal terisi air penuh dengan menggunakan metode irisan bidang luncur bundar Fellenius masingmasing adalah 3,25 dan 3,01 lebih besar dari angka aman 1,2, bendungan aman terhadap longsor. Pada tubuh bendungan bagian hulu kondisi gempa belum terisi air, dan bagian hulu kondisi normal gempa terisi air penuh masing-masing adalah 1,67 dan 1,54 lebih besar dari angka aman 1,2, bendungan aman terhadap longsor. pada tubuh bendungan bagian hilir kondisi normal belum terisi air, dan bagian hilir kondisi normal terisi air penuh masing-masing adalah 3,14 dan 2,87 lebih besar dari angka aman 1,2, bendungan aman terhadap longsor. Pada tubuh bendungan bagian hilir kondisi gempa belum terisi air, dan bagian hilir kondisi gempa terisi air penuh masing-masing adalah 1,79 dan 1,72 lebih besar dari angka aman 1,2, bendungan aman terhadap longsor.

\section{Saran}

Beberapa faktor berikut ini penting untuk dipertimbangkan guna kelancaran dalam melakukan penelitian:

1. Data yang digunakan dalam perhitungan juga harus dianalisis secara teliti dengan menggunakan berbagai macam teori yang ada. Sehingga dapat diperoleh hasil yang optimal dengan biaya ekonomis.

2. Pemilihan lokasi as bendungan perlu memperhatikan faktor sosial dan lingkungan masyarakat guna 
3. meminimalisir hambatan yang timbul akibat kurangnya koordinasi kepada masyarakat maupun instansi terkait.

\section{DAFTAR PUSTAKA}

Buana, H. 2010. Studi Perencanaan Dimensi Bendungan Rukoh Di DAS Rukoh - Tiro Kabupaten Pidie Provinsi Nanggroe Aceh Darussalam. Skripsi. Jurusan Teknik Sipil. UNIBRAW. Malang.

BWSSVII. 2015. Studi Kelayakan Pendahuluan Bendungan Air Luas. Penerbit BWS. Bengkulu.

Rifai, M., dan Kurniawan, D. 2008.

Perencanaan

Embung Pusporenggo Kabupaten

Boyolali, Jawa Tengah. UNDIP. Semarang. 